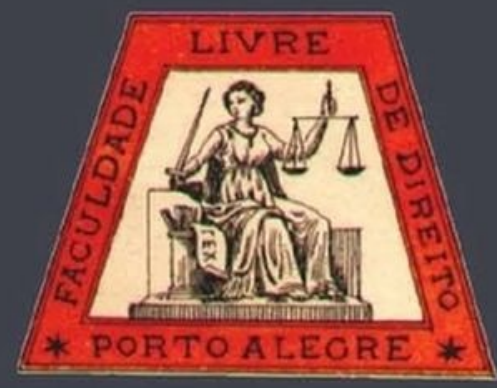

\title{
Financiamento de campanhas eleitorais no Brasil: uma análise legislativa, doutrinária e judicial
}

Electoral campaigns financing in Brazil: a legislative, doctrinal and judicial analysis

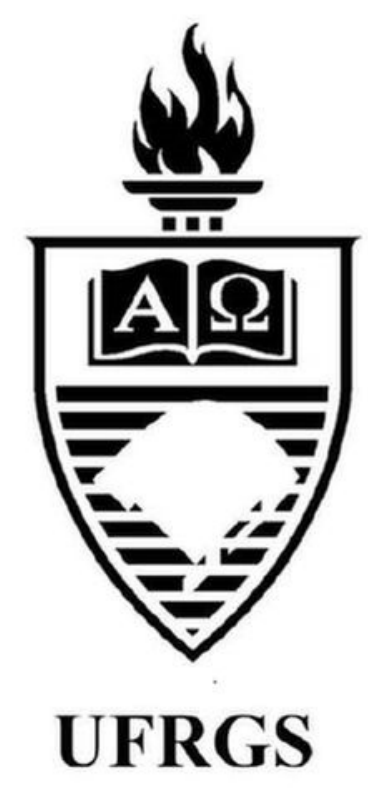

Marcelo Nunes Apolinário

Universidade Federal de Pelotas

Tatiana Afonso Oliveira

Universidade Federal de Pelotas 


\title{
Financiamento de campanhas eleitorais no Brasil: uma análise legislativa, doutrinária e judicial
}

\author{
Electoral campaigns financing in Brazil: a legislative, doctrinal and judicial analysis
}

Marcelo Nunes Apolinário*

Tatiana Afonso Oliveira**

\begin{abstract}
REFERÊNCIA
APOLINÁRIO, Marcelo Nunes; OLIVEIRA, Tatiana Afonso. Financiamento de Campanhas Eleitorais no Brasil: uma Análise Legislativa, Doutrinária e Judicial. Revista da Faculdade de Direito da UFRGS, Porto Alegre, n. 39, vol. esp., p. 263-287, dez. 2018.
\end{abstract}

\section{RESUMO}

O presente trabalho é resultado de uma pesquisa de cunho e metodologia bibliográfico e documental, e discute o financiamento de campanhas eleitorais como um dos temas dentro do grande debate da reforma política. Em um primeiro momento, elucida-se de que forma o financiamento de campanhas está inserido na reforma política. Posteriormente, passa-se a uma análise do histórico legislativo brasileiro sobre o tema do financiamento de campanhas eleitorais. Também são expostos alguns dos argumentos contrários e favoráveis aos sistemas público e privado de financiamento, além de se abordar de que forma se configura o atual sistema (misto). Ademais, abordar-se-á o estado da questão, que foi recentemente debatido pela Suprema Corte brasileira. Por fim, versa-se sobre a chegada da demanda ao STF como um caso de judicialização da política. Como resultados conclusivos da pesquisa, temos que: o financiamento de campanhas passou a ser regrado no Brasil à medida que o dinheiro passou a aumentar sua importância dentro dos diversos setores da sociedade; cada sistema apresenta aspectos positivos e negativos, e deve-se fazer uma boa análise a fim de se indicar o mais adequado à democracia brasileira; e, por fim, a questão sendo discutida no judiciário, mesmo trazendo à tona as discussões sobre o financiamento de campanhas e a reforma política, convidando a sociedade a debater sobre o tema, acaba por se transformar em mais um caso de judicialização da política no Brasil.

\section{PALAVRAS-CHAVE}

Democracia. Financiamento de Campanhas Eleitorais. Reforma Política.

\section{ABSTRACT}

This paper is the result of a bibliographical-documental research and discusses the electoral campaigns financing as one of the themes inside the political reform debate. At first, it elucidates how the campaigns financing is inserted in political reform. After that, it goes to an analysis of Brazilian legislative historical about the subject of electoral campaign financing. Some favourable and contrary arguments to private and public financings are exposed, moving further to an approach about the way Brazilian system is nowadays (mixed). Furthermore, the text treats of the question's current pertinence, which has been recently debated by Brazilian Supreme Court. Finally, it deals with the litigation arrival to the STF as a case of politics judicialization. As conclusive results of the investigation, we have that the campaigns financing started being ruled in Brazil as soon as money had its importance increased in different sectors of society; each system presents negative and positive aspects and we must make a good analysis in order to point the most suitable to Brazilian democracy; and, finally, the subject being discussed in judiciary, although bringing to light the discussions about. campaigns financing and political reform, inviting society to debate about. the theme, ends by becoming one more case of politics judicialization in Brazil.

\section{KEYWORDS}

Democracy. Electoral Campaigns Financing. Political Reform.

\footnotetext{
* Professor da Faculdade de Direito da Universidade Federal de Pelotas (UFPEL). Doutor em Direito pela Universidad Autónoma de Madrid.

** Graduada em Direito pela Universidade Federal de Pelotas (UFPEL).
} 


\section{SUMÁRIO}

Introdução. 1. O Financiamento de Campanhas e a Reforma Política. 2. O Financiamento de Campanhas no histórico legislativo. 3. Sistemas Existentes. 3.1. O atual sistema: Misto. 3.2. Financiamento Público. 3.3. Financiamento Privado. 4. O Financiamento de Campanhas chega ao STF: ADI 4.650. 4.1 Os argumentos pela procedência e improcedência da ação. 4.2. Como fica o Financiamento no Brasil pós-contenda no STF? 5. A Judicialização da Política no caso da ADI 4.650. Conclusão. Referências.

\section{INTRODUÇÃO}

O presente trabalho, de cunho e metodologia bibliográfico e documental aborda o tema do Financiamento de Campanhas Eleitorais no Brasil. Objetivando traçar observações descritivas e paralelamente críticas sobre diversos aspectos envolvendo o tema, a presente investigação dedica-se a uma análise legislativa, doutrinária e judicial do mesmo.

Em um primeiro momento, será feito um paralelo entre o financiamento de campanhas eleitorais e a reforma política, demonstrando-se de que forma aquele está contido dentro desta. Nesse ponto, buscar-se-á comprovar o porquê de se considerar impensável a Reforma Política no Brasil sem que se leve em conta o Financiamento de Campanhas Eleitorais. Isso, principalmente, porque o modo como as campanhas serão financiadas é determinante no modo como funcionará a política no Brasil.

Posteriormente, analisar-se-á o histórico legislativo brasileiro acerca do financiamento de campanhas eleitorais. Comprovar-se-á que a legislação pátria passou a dar importância à influência do dinheiro nas eleições na medida em que o poder econômico passou a ter grande importância nos demais setores da sociedade, principalmente, a partir da era Vargas.

Ademais, será possível observar que o tema do Financiamento de Campanhas Eleitorais é um assunto sempre recorrente na legislação brasileira. De modo que, desde sua primeira regulamentação por Lei, jamais parou de ser debatido tanto no âmbito social como no políticojurídico.

Após, abordar-se-á de que forma o financiamento de campanhas pode ser institucionalizado em um Estado, ou seja, os sistemas de financiamento de campanhas eleitorais existentes. São eles: financiamento público, financiamento privado e financiamento misto.

Explicar-se-á as nuances de cada sistema, bem como as vantagens e desvantagens na adoção de um ou de outro. Além do mais, aprofundar-seá na questão de por qual motivo o Financiamento de Campanhas Eleitorais no Brasil é considerado um sistema misto, ou seja, com uma fração pública e outra fração privada.

Em um momento posterior, analisar-se-á a chegada do debate sobre o Financiamento de Campanhas Eleitorais ao Supremo Tribunal Federal através de uma Ação Direta de Inconstitucionalidade proposta pelo Conselho Federal da Ordem dos Advogados do Brasil: a ADI 4.650.

Nesse ponto, demonstrar-se-ão quais os fundamentos do Conselho Federal da OAB para propor a referida Ação. Procurar-se-á esclarecer cada um deles, de maneira que possam contribuir para que se tragam mais elementos e argumentos para o debate sobre o financiamento de campanhas eleitorais.

Mais adiante, serão analisados os principais argumentos utilizados pelos julgadores (Ministros do Supremo Tribunal Federal) na avaliação da referida contenda. Buscar-se-á elucidar os 
argumentos-chave levados em conta para os que votaram pela procedência da Ação e para aqueles que entenderem ser caso de improcedência.

Não obstante, na mesma toada, será realizado uma abordagem geral sobre como se encontra atualmente regulamentado o Financiamento de Campanhas Eleitorais no Brasil. Ou seja, após a importante decisão do Supremo Tribunal Federal que foi, sem dúvida, um marco na história do financiamento de campanhas eleitoral, faz-se necessário pontuar como restou regulamentado o assunto. Para tanto, além de abordar os efeitos da decisão, pretende-se despender um olhar sobre as legislações que surgiram sobre o assunto já após a publicação do acórdão da referida Ação Direta de Inconstitucionalidade.

Então, no último tópico, realizar-se-á uma análise sobre de que forma a chegada da questão ao Supremo Tribunal Federal é mais uma ocorrência de judicialização da política no Brasil. Nesse ponto, será estudada a questão idealizada por Montesquieu sobre a separação dos poderes de uma Democracia em três, ou seja, a tripartição dos poderes em Legislativo, Executivo e Judiciário. Ademais, procurar-se-á entender no que consiste o fenômeno da Judicialização da Política, bem como suas causas e consequências. E, dessa forma, demonstrar o porquê de a Judicialização da Política ser um fator que descaracteriza e desestabiliza a ideia da Tripartição dos Poderes proposta por Montesquieu bem como a ideia de Democracia propriamente dita.

Por fim, será feito um levantamento geral acerca das discussões apresentadas. Buscar-se-á esclarecer as conclusões e os resultados obtidos ao longo do estudo.

\section{O FINANCIAMENTO DE CAMPANHAS E A REFORMA POLÍTICA}

Desde o início da década de 90 se discute a necessidade de alterações na política brasileira, cujo modelo em vigor favorece a falta de transparência, o fisiologismo partidário (troca de favores) e a predominância do fator econômico e outras situações que enfraquecem o exercício da democracia e da cidadania em nosso país. Todavia, Projetos de Leis que tramitam no Congresso Nacional e que contrariam em grande parte os interesses dos parlamentares e governantes do Executivo fizeram com que, por muito tempo, a reforma nunca fosse votada. Segundo Lima (2010, p. 42), "[a] reforma política está presente na democracia, inserida em um contexto mais amplo que necessariamente diz respeito a mudanças no próprio sistema político, diz respeito à cultura do eleitor e [à] política desenvolvida pelo Estado.”.

A democracia brasileira consiste em uma "democracia eleitoral", ou seja, há eleições periódicas e liberdade de expressão, entretanto, falta igualdade material capaz de promover uma democracia plena. Devido ao afastamento entre eleitores e políticos e pelo fato de as instituições atuais não estarem cumprindo os objetivos da Constituição, a sociedade vem clamando por uma reforma no modelo político brasileiro. (FÓRUM SOCIAL BRASILEIRO, 2014, p. 11).

$\mathrm{E}$, ao reformar-se a democracia brasileira, é de extrema importância que seja revista a questão do financiamento de campanhas eleitorais. O financiamento de campanhas não só é um dos tópicos a serem debatidos na reforma política, como também é um dos temas de maior efervescência no momento. Escândalos de corrupção envolvendo a parceria entre grandes empresas e políticos detentores de mandato fazem com que o assunto volte à tona e a sociedade clame por uma reforma nesse sentido. 
Assim sendo, seria inadmissível hoje haver uma reforma política no Brasil sem que essa aborde o tema do financiamento de campanhas eleitorais. Há a sensação de que a_população demanda que sejam revistos os meios pelos quais os políticos chegam ao poder, para que estejamos mais perto de concretizar os ideais de justiça e igualdade.

A reforma política é um gênero no qual se encontram diversas espécies. Ou seja, dentro desse grande tema há vários assuntos a serem debatidos e revistos, como: sistemas eleitorais, voto obrigatório, fidelidade partidária, presidencialismo de coalizão, entre tantos outros. O presente trabalho dedica-se a um dos temas da reforma política em específico: o financiamento de campanhas eleitorais.

\section{O FINANCIAMENTO DE CAMPANHAS NO HISTÓRICO LEGISLATIVO}

É evidente que a regulamentação do poder econômico sobre as eleições no Brasil não é tão antiga quanto o processo eleitoral e o voto em sentido amplo em nosso país. Por muito tempo, tivemos eleições (mesmo não havendo sufrágio universal) onde sequer era cogitado observar e normatizar a interferência do dinheiro. Por conseguinte, as eleições no Brasil ocorrem há muito mais tempo que a observância sobre o financiamento das campanhas. Logo, por muito tempo, tivemos eleições desregradas no que tange à questão financeira.

Como bem observa Ulpiano no Corpus Iuris Civilis, "Ubi homo ibi societas; ubi societas, ibi jus" (onde está o homem, aí está a sociedade; onde está a sociedade, aí está o direito). Dessa forma, havendo mudança na sociedade, o direito também mudou. E, assim, com o fim da República Velha e a primeira parte da era Vargas, a industrialização no Brasil deu um salto, e com isso, o poder econômico passou a se dissipar em nossa sociedade.
Consequentemente, setores sociais vinculados à causa se articularam com o propósito de pressionarem a classe política a editarem regras que tivessem direcionadas no sentido de fiscalizar e controlar o poder econômico no tocante aos processos eleitorais. A Carta Magna de 1934, ao dar valor constitucional para a Justiça Eleitoral e ao destinar no corpo do seu texto uma seção específica, abriu grandes portas para uma maior regulamentação do processo eleitoral, inclusive no que tange à influência do dinheiro. Em 1932, com o advento do Código Eleitoral (reformado em 1950 e não mais vigente hoje), pela primeira vez o financiamento de campanhas eleitorais é disciplinado de forma explícita pela legislação brasileira.

\begin{abstract}
A revolução de 1930 e o primeiro período Getulista (1930-1945), na medida em que representaram a superação de boa parte do modelo político, social e econômico da República Velha, parecem ter sido marcos importantíssimos também para a questão do financiamento de campanhas. (...)

$\mathrm{E}$ os primeiros passos nesse sentido não tardaram. De fato, as transformações pela quais o país passou ao longo do primeiro período getulista acabaram por propiciar o advento de uma legislação que contemplava o problema das finanças partidárias. Com efeito, o Código Eleitoral de 1950 (Lei n. 1.164, de 24 de julho de 1950) estabeleceu a fiscalização das contas dos partidos pela Justiça Eleitoral, a obrigatoriedade do rigoroso registro das receitas e despesas partidárias e a vedação do recebimento de contribuições de entidades estrangeiras, autoridades públicas, sociedades de economia mista ou concessionárias de serviços públicos. (MACHADO, 2008, p. 185-186).
\end{abstract}

Mais tarde, com o período militar, a política brasileira sofreu um grave retardamento. Entretanto, mesmo não havendo eleições que retratassem a legítima vontade da maioria, houve grande preocupação com o financiamento de campanhas.

Com o objetivo de não deixar crescerem os partidos de oposição, muitos diplomas legais sobre o tema foram criados nesse período. 
Embora com o objetivo de impedir a Democracia, surgiram legislações de vital importância para o financiamento de campanhas eleitorais, inclusive legislações que têm extrema importância atual. Foi justamente na ditadura militar brasileira que foi criado o Código Eleitoral que vigora até os dias de hoje (Lei 4.737, de 15 de julho de 1965). E, no mesmo dia, foi criada a Lei de Organização dos Partidos Políticos (Lei 4.740/65). Essa foi revogada pela Lei Orgânica dos Partidos Políticos (Lei 5.682, de 21 de julho de 1971).

A grande inovação trazida pela Lei de Organização dos Partidos Políticos foi que, a partir dela, o sistema de financiamento de campanhas eleitorais no Brasil passou a ser misto (público e privado), sistema este que vigora até os dias de hoje. Tal mudança ocorreu devido à introdução do "Fundo Partidário". Além disso, transformou os partidos políticos em pessoas jurídicas de direito público interno. Entretanto, tendo havido a revogação do referido diploma legal de 1965 pela Lei Orgânica dos Partidos Políticos e, posteriormente, dela pela Lei 9.096 de 1995, os partidos políticos passaram a ser pessoas jurídicas de direito privado.

Finda a ditadura militar, houve a abertura política no Brasil e a redemocratização. Já após o período de promulgação da Constituição Federal de 1988, tivemos a edição de duas Leis de extrema importância para a matéria: Lei 9.096, de 19 de setembro de 1995 e Lei 9.504 , de 30 de setembro de 1997, ambas em pleno vigor. Esta última é que traz os limites para as doações de pessoas físicas e jurídicas. As pessoas físicas podem doar até dez por cento dos rendimentos brutos auferidos no ano anterior à eleição ${ }^{2}$. E às pessoas jurídicas, a

\footnotetext{
1“O Fundo Especial de Assistência Financeira aos Partidos Políticos, denominado Fundo Partidário, é constituído por dotações orçamentárias da União, multas, penalidades, doações e outros recursos financeiros que lhes forem atribuídos por lei.

Os valores repassados aos partidos políticos, referentes aos duodécimos e multas (discriminados por partido e relativos ao mês de distribuição), são publicados mensalmente
}

limitação era de dois por cento do faturamento bruto do ano anterior à eleição ${ }^{3}$.

As Leis 9.504/1997, 9.096 de 1995 e o próprio Código Eleitoral de 1965, foram recentemente alterados pela Lei 13.165/2015, a qual tratou de diversos temas da Reforma Política, como a participação feminina no processo eleitoral, percentual mínimo para as eleições do sistema proporcional, regulamentações dos partidos políticos, etc. Mais especificamente, em relação ao Financiamento de Campanhas Eleitorais, sua principal mudança foi o fim da possibilidade de doações provenientes de pessoas jurídicas, restando apenas as doações de pessoas físicas e os recursos próprios dos candidatos. Tudo indo ao encontro da anterior decisão do Supremo Tribunal Federal em proibir as doações advindas de pessoas jurídicas.

A atual legislação em vigor sobre o financiamento de campanhas eleitorais, bem como o teor da supracitada decisão serão tratadas posteriormente no presente trabalho, em tópico específico destinado ao modo como hoje se encontra regulamentado o financiamento de campanhas.

Mais recentemente, disciplinando a mesma matéria, tem-se as Leis 12.034, de 29 de setembro de 2009 e 12.891, de 11 de dezembro de 2013, as quais não trouxeram substanciais inovações na forma de financiamento das campanhas eleitorais.

Dessa forma, nota-se que, por algum tempo, tivemos eleições nas quais o financiamento de campanhas eleitorais não era regulamentado. Depois, começando com regulamentações tímidas e generalizadas, a legislação foi evoluindo até que se chegasse ao patamar alcançado nos dias atuais, com legislações eleitorais específicas sobre o

no Diário da Justiça Eletrônico. A consulta pode ser realizada por meio do acesso ao sítio eletrônico do TSE na Internet." (Retirado do sítio eletrônico do Tribunal Superior Eleitoral na Internet).

2 Artigo 23, parágrafo $1^{\circ}$, inciso I, da Lei $n^{\circ} 9.504$ de 30 de setembro de 1997, antes das reformas sofridas em 2015.

3 Artigo 81, parágrafo $1^{\circ}$, da Lei $n^{\circ} 9.504$ de 30 de setembro de 1997, antes das reformas sofridas em 2015. 
financiamento de campanhas eleitorais e com constantes modificações de conteúdo por parte dos representantes políticos e até mesmo por membro do Poder Judiciário. Fica evidente que tal movimentação legislativa e judicial sobre o financiamento de campanhas eleitorais se dá devido ao fato da enorme influência que o dinheiro e o poder econômico são capazes de exercer sobre o pleito eleitoral.

A seguir, analisar-se-ão as formas pelas quais o dinheiro pode movimentar o andamento de uma eleição, ou seja, os sistemas de financiamento de campanhas eleitorais.

\section{SISTEMAS EXISTENTES}

No presente apartado, abordar-se-ão os sistemas de financiamento de campanhas eleitorais existentes. Pretende-se analisar as características principais de cada um, bem como os aspectos positivos e negativos que apresentam em seu funcionamento.

\subsection{O atual sistema: Misto}

Muito se ouve na mídia e em outros meios a respeito das doações de empresas privadas às campanhas políticas no Brasil. Critica-se a extrema influência que grandes empresas têm no processo eleitoral e, posteriormente, sobre os políticos eleitos. Muitas vezes, quem não se aprofunda no tema do financiamento de campanhas eleitorais e ouve apenas a mídia e o senso comum, chega a crer que, no Brasil, as campanhas eleitorais ocorrem simplesmente devido a doações de grandes empresas de iniciativa privada.

Então, como se trata de uma investigação de natureza acadêmica, passa-se agora a esclarecer como funciona o financiamento de campanhas eleitorais no Brasil: trata-se de um sistema misto, ou seja, público e privado que interagem concomitantemente.
O financiamento público é referido na própria Constituição Federal, no parágrafo terceiro do artigo 17, que descreve: "Os partidos políticos têm direito a recursos do fundo partidário e acesso gratuito ao rádio e à televisão, na forma da lei". Observa-se, então, que a parte pública do financiamento de campanhas no Brasil advém do Fundo Partidário.

Infraconstitucionalmente, o Fundo Partidário está regulamentado na Lei 9.096/95. Em seu artigo 38 e nos quatro incisos que o seguem, está prevista a forma pela qual o fundo partidário será composto. Já no artigo 41-A, destaca de que maneira tal fundo será distribuído entre os partidos políticos. E o inciso III do artigo 44 do mesmo texto normativo prevê a aplicação de recursos do Fundo Partidário em campanhas eleitorais.

Já a fração privada do financiamento das eleições é composta de duas fontes: doações de pessoas físicas e recursos próprios dos candidatos. O financiamento privado encontra-se citado, por exemplo, na Lei 9.504/97. Nos dois incisos do parágrafo primeiro do artigo 23 da Lei, são estabelecidos os limites a serem seguidos nas doações de pessoas físicas e na utilização de recursos do próprio candidato à eleição.

Havia, ainda, a parte do financiamento por parte das pessoas jurídicas de direito privado, entretanto, tal possibilidade foi encerrada pela Ação Direta de Inconstitucionalidade 4.650 proposta pela Ordem dos Advogados do Brasil perante o Supremo Tribunal Federal. Além disso, tal vedação foi confirmada pela legislação subsequente, que revogou os dispositivos que tratavam das doações de pessoas jurídicas, como será visto adiante.

Entretanto, há países onde se encontra em vigor um sistema misto que conta com a participação das pessoas jurídicas na doação de recursos para as campanhas eleitorais. Por muito tempo foi o caso do Brasil. 
Enfim, nos países onde vigora o sistema misto, cada um funcionará de uma forma, a depender da previsão legal vigente em cada um. Nos Estados Unidos, por exemplo, empresas não podem doar diretamente para os candidatos, mas têm a possibilidade de inserir dinheiro nos Comitês de Ação Política, os chamados PACs.

Os PACs não são oficialmente ligados às campanhas e podem arrecadar dinheiro sem limites de empresas e indivíduos para apoiar um candidato ou atacar adversários. O mecanismo é fortemente criticado por ONGs, juristas e ativistas. (Jean-Philip Struck, 2017, acesso online).

É importante que fique destacado que, apesar de não mais existir a possibilidade legal de doações por parte de pessoas jurídicas com o intuito de fomentar o pleito eleitoral, o sistema de financiamento de campanhas no Brasil segue sendo o misto. Isso porque possui a parte pública advinda do fundo partidário, mas também há previsão de recursos privados, os quais são advindos de doações de pessoas físicas nos limites estabelecidos em Lei, bem como recursos próprios de candidatos.

Apesar de o sistema de financiamento de eleições no Brasil ser misto, muito se discute sobre as vantagens e desvantagens de um financiamento exclusivamente público ou exclusivamente privado. Aqueles que são contrários ao financiamento público de campanhas eleitorais argumentam no sentido de que dinheiro que poderia ser destinado à saúde, educação, etc., seria utilizado com os interesses político-partidários. Já os favoráveis afirmam que tal sistema reduziria a corrupção e a desigualdade entre os candidatos (RIBEIRO, 2006, p. 78). A seguir, abordar-se-ão exemplos de alguns aspectos vantajosos e desvantajosos de cada um dos dois sistemas.

\subsection{Financiamento Público}

Uma das vantagens elencadas a respeito do financiamento público de campanhas eleitorais é que tal modalidade fortaleceria os partidos políticos, os quais se encontram enfraquecidos. Percebe-se uma crescente valorização da pessoa individual e desvalorização do partido em seu conjunto. Ou seja, muitas vezes determinados candidatos possuem mais expressão política ou social que seus próprios partidos, ou então, os partidos necessitam de candidatos com alto valor de aparição na mídia. Dessa forma, acaba ocorrendo que o político vale mais que o partido, quando deveria ser ao contrário. Na democracia representativa, os partidos deveriam sem fortes e atuantes, e o candidato deveria ser apenas mais um a formar um grupo em nome do partido. Então, no financiamento puramente público, os recursos iriam diretamente para o partido em si, e não para cada candidato individualmente. Sendo assim, a sigla seria fortalecida, já que o partido seria responsável por determinar como funcionariam os gastos da campanha de cada político, fazendo com que esses agissem pelo partido, quebrando a tendência atual de personificação de um ou alguns candidatos em detrimento do partido em sua totalidade.

Outra virtude dessa modalidade de financiamento é que tal conferiria maior transparência ao processo eleitoral. É sabido que tudo o que passa pela fiscalização do Estado tem, no mundo do dever-ser, menos chances de estar corrompido de ilegalidade, já que o governo está subordinado à legislação no Estado de Direito, e são deveres dele criar a Lei, fazê-la cumprir e julgar quando não for cumprida. Assim sendo, sem interferência de entes externos ao Estado, promover a transparência do processo eleitoral e combater a corrupção parece ser mais fácil. Entretanto, não se quer aqui dizer que a implementação do modelo público de financiamento de campanhas eleitorais acarretaria 
o fim absoluto da corrupção. Como bem salienta Caggiano (2004, p. 119), "a corrupção não pode ser entendida como um estigma peculiar e particular ao campo do financiamento políticopartidário-eleitoral.".

Ademais, o financiamento público exclusivo geraria maior igualdade de condições na disputa das eleições. Atenuar-se-iam as críticas de que o sistema eleitoral e, mais especificamente, o modo como são financiadas as campanhas, ferem o princípio da igualdade expresso na Constituição Federal, o qual é um dos pilares do direito liberal. Tanto os candidatos que se relacionam bem com empresas e doadores pessoas físicas quanto aqueles que repudiam qualquer interesse empresarial ou particular teriam maior igualdade nas disputas pelos mandatos políticos. Não se fala aqui de uma igualdade utópica, entretanto, acredita-se, sim, que o financiamento público traria bem mais condições para que o princípio da igualdade fosse cumprido e cada vez mais efetivado no plano material.

Aspecto positivo também levantado pelos defensores do sistema exclusivamente público é que se reduziriam os gastos com campanhas eleitorais e privilegiar-se-ia o conteúdo das propostas em detrimento da extrema valorização do marketing e da imagem. Alguns acreditam que, se o financiamento fosse público, o Estado haveria de diminuir bastante o dispêndio com campanhas eleitorais.

Por fim, certos estudiosos acreditam que a maior crítica ao modelo de financiamento de campanhas que conta com doações privadas desapareceria se ele se tornasse público: o fato de que os candidatos ficam presos aos seus financiadores e, depois de eleitos, acabam tendo que retribuir os favores, o que gera uma observância de interesses particulares de empresários, quando, na verdade, os políticos são eleitos para representar a vontade da sociedade e pugnar pelos interesses do povo enquanto coletividade.

O atual processo gera uma aproximação viciada entre candidatos e financiadores, numa relação de dívida de um para com o outro. Tal fato fica comprovado nas casas legislativas através dos inúmeros escândalos de relação promíscua entre estas e empresas particulares (TEIXEIRA FILHO, 2013, p. 27).

Com o advento do financiamento público exclusivo, os candidatos não mais dependeriam do dinheiro de empresários e doadores particulares e, portanto, não precisariam retribuir favor algum no curso de seu mandato o que, espera-se, deixaria o eleito mais livre para governar na observância da ética e dos interesses da sociedade.

Entretanto, um ponto desfavorável dirigido a essa modalidade de financiamento é o de que esse modelo pode privilegiar as decisões das cúpulas partidárias, uma vez que será ela, a cúpula, que decidirá como serão gastos esses recursos. Dessa forma, poderia ocorrer de os políticos mais bem relacionados com os líderes partidários receberem mais recursos simplesmente por esse motivo. Ou que candidatos que desagradam os líderes, sejam "prejudicados" recebendo montantes extremamente inferiores. Assim sendo, alguns políticos poderiam ficar sem ter como recorrer a outras formas de arrecadação de dinheiro, visto que o financiamento seria exclusivamente público e, portanto, as doações de pessoas físicas, jurídicas e recursos próprios do candidato não mais poderiam ser utilizados em sua campanha.

Além disso, alguns levantam a possibilidade de o financiamento público tornar os partidos extremamente dependentes do Estado, o que acarretaria uma acomodação dos mesmos. Como não precisariam de recursos outros (e nem poderiam) além dos provenientes do Estado, não 
se veriam obrigados a ouvir reivindicações de seus filiados.

Pode-se destacar, também, entre as críticas ao financiamento público exclusivo, aquela que observa que recursos estatais que deveriam servir para financiar a educação, a saúde, o saneamento básico, a segurança, o transporte, etc., iriam para a política, um setor que goza de escassa credibilidade entre a população. $\mathrm{O}$ afastamento entre a sociedade e a política explica o porquê de esta não querer ver os seus impostos destinados à atividade político-partidária. A população, de forma geral, está descrente da política e prefere os cofres públicos envolvidos em outros setores.

\subsection{Financiamento Privado}

O sistema privado de financiamento de campanhas eleitorais é alvo de muitas críticas. Ao discorrer acerca do sistema privado, a maioria dos autores rechaça essa possibilidade de sistema no Brasil e expõe propostas contrárias.

O financiamento privado das campanhas eleitorais é um dos temas mais discutidos no âmbito da reforma política brasileira. Diversas são as propostas que pretendem alterar a regulamentação legal das doações para as campanhas, com o objetivo de tornálas verdadeiramente democráticas e menos dependentes do poder econômico. (PEREIRA; VIDAL, 2014, p. 392).

Pode ser verdade que, para uma Democracia que não está totalmente amadurecida, como é o caso da nossa, o sistema exclusivamente privado não seja o mais adequado, entretanto, seria errado ignorar que tal sistema possui suas vantagens. E, evidentemente, há aspectos negativos, os quais também serão abordados ainda neste mesmo tópico.

O sistema é, por vezes, defendido por setores de orientação política mais atrelados à

${ }^{4}$ Disponível em: <https://novo.org.br>. Acesso em: 01 nov. 2018. direita. Existem programas partidários que defendem o fim de dotações orçamentárias públicas destinadas a partidos políticos e campanhas eleitorais, como é o caso do programa apresentado pelo Partido Novo ${ }^{4}$.

Um ponto positivo que poderia ser dado ao modelo de financiamento privado das campanhas eleitorais é que ele tem caráter liberal e maior abertura. As decisões não ficariam simplesmente nas mãos das cúpulas dos partidos: as pessoas (sejam filiados ou a sociedade em geral) teriam mais vez e voz. Poderia participar do processo de doação para campanhas quem quisesse, sejam pessoas externas aos partidos, filiados, simpatizantes e, inclusive, empresas.

Além disso, tal sistema é extremamente simples, pois as doações podem vir de qualquer fonte (desde que lícita) e no montante desejado por cada particular. Dessa forma, o Estado não precisaria intervir e regulamentar utilizando critérios para a divisão dos recursos entre os partidos políticos. A “mão invisível” do mercado agiria sozinha em uma relação puramente liberalista.

Por fim, sumiriam as críticas relativas a recursos públicos que deveriam ser utilizados em serviços básicos essenciais (saúde, educação, segurança, etc.) serem utilizados para a política. Se os gastos fossem exclusivamente privados, o Estado estaria isento de participar na construção das campanhas eleitorais.

Passando aos aspectos negativos do financiamento privado, destaca-se a principal crítica por ele sofrida: é um sistema que fomenta a troca de favores. Políticos, que deveriam estar livres para governar em nome do povo, acabam ficando presos àqueles particulares que contribuíram com suas campanhas. Dessa forma, acabam atentando contra um dos maiores cânones do direito moderno: a prevalência dos interesses sociais sobre os interesses particulares. 
Além disso, o sistema fomenta a corrupção, na medida em que os eleitos passam a ter que tomar atitudes antiéticas e, possivelmente, ilícitas para poderem "pagar" o que fora prestado pelas empresas no curso de suas campanhas eleitorais.

Pode-se destacar, também, que o financiamento privado tem um caráter extremamente desigual, já que não há qualquer controle estatal no sentido de garantir que os candidatos tenham possibilidades iguais durante $o$ pleito. Um candidato que, por ideologia, não quer se render às vontades empresariais, acaba ficando para trás na corrida eleitoral se comparado àquele que recebe suporte financeiro de quem tem poder econômico. Segundo Fleischer (2004, apud FLEISCHER; LÚCIO; REIS, 2009), o modelo de financiamento privado faz com que o candidato mais abastado economicamente seja favorecido na eleição.

Enfim, outra possível crítica a ser feita é a de que o modelo desestabiliza e torna os partidos mais fracos e figurantes, ao invés de protagonistas. Os interesses particulares ficam acima da ideologia partidária. Assim sendo, os partidos políticos passam a ter um papel secundário na democracia quando, na verdade, deveriam ter extrema relevância. Também, figuras de candidatos passam a ter mais valor que o próprio partido, numa espécie de "personalismo" em vez de partidarismo. Os partidos políticos passam a ser uma mera burocracia para que os candidatos (com ideais próprios e que talvez não condigam com os ideais do partido) cheguem ao poder.

Conforme o exposto, resta evidente que ambos os modelos apresentam características positivas e negativas. É necessário que se siga estudando qual sistema melhor se encaixa na forma como a Democracia brasileira está hoje estruturada, a fim de que as Leis que regulam a disputa pela chegada ao poder sejam justas e compatíveis com nossa sociedade. Conforme Martins (2004, p. 114), “apenas a lei pode reduzir o nível de inconfiabilidade do 'bom' no poder e a principal das Leis para essa finalidade é aquela que regula o acesso ao poder, principalmente no que diz respeito aos meios econômicos para atingi-lo".

\section{O FINANCIAMENTO DE CAMPANHAS CHEGA AO STF: ADI 4.650}

A discussão foi trazida à tona, nos últimos tempos, devido a uma Ação Direta de Inconstitucionalidade proposta pelo Conselho Federal da Ordem dos Advogados do Brasil perante o Supremo Tribunal Federal.

O que o Conselho Federal da OAB solicita é que sejam declarados inconstitucionais certos dispositivos das Leis 9.096/95 e 9.504/97, que tratam sobre financiamento de partidos políticos e campanhas eleitorais. O argumento utilizado é que o modo como atualmente (leia-se, na época da propositura da Ação) está regulado o financiamento de campanhas eleitorais faz com que as mesmas tenham muita influência do poder econômico, o que ofende os seguintes princípios expressos na Constituição Federal: democrático (arts. $1^{\circ}$, caput e parágrafo único; 14, caput; 60, $\S 4^{\circ}$, II), republicano (art. $1^{\circ}$, caput) e da igualdade (arts. $5^{\circ}$ e 14 ).

Em um primeiro momento, requereu que fosse declarada a inconstitucionalidade parcial do artigo 23 da Lei 9.504/97, apenas na parte em que autorizada a doação por pessoas jurídicas a campanhas eleitorais. Além disso, solicitou a declaração de inconstitucionalidade do artigo 81, caput e parágrafo $1^{\circ}$ do referido diploma legal. Em ambos os casos faz o pedido da atribuição de eficácia ex nunc à decisão.

Ademais, pede a declaração de inconstitucionalidade parcial do art. 31 da Lei 9.096/95, no trecho em que permite a doação de pessoas jurídicas a partidos políticos. Em continuidade, a inconstitucionalidade da expressão "ou pessoa jurídicas", presente no art. 
38, inciso III, da referida Lei, bem como a expressão "e jurídicas", posta no art. 39, caput e parágrafo $5^{\circ}$ da mesma Lei. Em todos os casos, pleiteia a atribuição de eficácia ex nunc à decisão.

A OAB solicita, também, a declaração de inconstitucionalidade do art. $23, \S 1^{\circ}$, incisos I e II, da Lei 9.504 de 1997, que é justamente o artigo que tratava dos limites de doações a campanhas eleitorais por pessoa naturais e limites de recursos advindos do próprio candidato. Entretanto, neste ponto, o Conselho Federal faz uma ressalva: a permissão de que tais dispositivos mantenham eficácia por mais 24 meses, para que não ocorra uma lacuna jurídica que represente perigo ao regramento do limite às doações de campanha realizadas por pessoas naturais e ao uso de recursos próprios dos candidatos.

Já em relação ao art. 39, parágrafo $5^{\circ}$, da Lei 9.096/95, a OAB solicita sua declaração de inconstitucionalidade, entretanto, com manutenção de sua eficácia por até 24 meses, para não haver criação de lacuna jurídica no sentido de inexistência de limitação na doação de pessoas naturais a partidos políticos. Todavia, tal ressalva de manutenção da eficácia não se estende à expressão "e jurídicas" constante no referido parágrafo, ou seja, em relação às pessoas jurídicas, pugna pela imediata exclusão de sua possibilidade de participação nas doações aos partidos políticos.

Por fim, solicita que o Congresso Nacional estabeleça um novo limite para doações de pessoas naturais a partidos políticos ou campanhas eleitorais, bem como um novo limite para utilização de recursos próprios do candidato em campanha eleitoral. Em ambos os casos, o critério do limite a ser fixado seria per capita. Ademais, solicita que, caso o Congresso Nacional não o faça, seja repassada ao Tribunal Superior Eleitoral a competência para regulamentar de forma provisória tal questão.

Em suma, o acolhimento dos pedidos do Conselho Federal da Ordem dos Advogados do
Brasil acarretaria no fim da participação das Pessoa Jurídicas nas doações em processos eleitorais, bem como o fim do limite das doações de Pessoas Naturais e dos limites de recursos advindos do próprio candidato na forma em que se encontra. A manutenção dos referidos limites duraria por até 24 meses, quando seria substituído por um limite per capita, a ser instituído pelo Congresso Nacional ou, subsidiariamente, em caso de omissão da casa legislativa, pelo Tribunal Superior Eleitoral de forma provisória.

Basicamente, os argumentos utilizados pela $\mathrm{OAB}$ na propositura da Ação são os relativos à afronta aos princípios da igualdade, princípio democrático e princípio republicano.

O Conselho Federal da Ordem dos Advogados do Brasil sustenta que o financiamento de campanhas eleitorais por parte das pessoas jurídicas e das pessoas naturais e candidatos, do modo como está (em verdade, "estava", eis que a ação foi julgada parcialmente procedente, entretanto, utiliza-se aqui a argumentação no tempo verbal que outrora fora proferida pela $\mathrm{OAB}$ ) regulamentado acaba por ferir o Princípio da Igualdade, disposto de forma genérica no art. $5^{\circ}$, caput, da Constituição Federal e, de forma específica ao campo político, no artigo 14 do Texto Constitucional em seu caput.

Em relação a tal princípio, a OAB entende que, no constitucionalismo contemporâneo, a igualdade é uma meta a ser atingida, e não uma realidade posta a ser meramente protegida. $\mathrm{Ou}$ seja, nas Democracia atuais, a igualdade formal não é capaz de abarcar a realidade social, política e econômica. O que se necessita é de uma igualdade material a ser perseguida pelo Estado. No atual contexto político-social-econômico, há de se conceber e encarar o fato de que a realidade nas três esferas é extremamente desigual, devendo o poder político promover sua reparação, e não meramente proclamar uma igualdade formal inexistente. 
O atual (frisa-se, atual à época da propositura da ação) regime de financiamento de campanhas eleitorais, segundo a concepção do legitimado ativo da referida contenda, fere o princípio da igualdade porque, em vez de corrigir as citadas desigualdades, as promove. Isso porque permite que os mais abastados economicamente (ou que possuam mais contatos economicamente abastados) tenham maior controle sobre $\mathrm{o}$ processo eleitoral e, consequentemente, sobre o Estado. Assim, não há igualdade alguma, haja vista que o Estado fica apenas a mercê dos mais poderosos e das empresas mais poderosas.

Todos deveriam ter iguais possibilidades de interagirem no processo eleitoral e de buscar a aceitação de suas ideias por parte do coletivo e da população votante. Entretanto, o que se tem observado, segundo a OAB, é um sistema onde a desigualdade econômica promove a desigualdade política, ferindo a representatividade.

Em sequência, o Conselho Federal passa uma argumentação no tocante à ofensa ao Princípio Democrático. Afirma a $\mathrm{OAB}$ que o Princípio Democrático é o princípio basilar de toda a Constituição Federal de 1988, haja vista ter sido ele que definiu o fim do regime autoritário no Brasil e o início do período democrático. Tal postulado está abarcado em diversos pontos da Constituição Federal, como a cláusula do Estado Democrático de Direito (art. $1^{\circ}$, caput), a menção à fonte popular do poder (art. $1^{\circ}$, Parágrafo Único) e a garantia do sufrágio universal pelo voto direto, secreto, e com valor igual para todos (art. 14), que foi, inclusive, elevada à condição de cláusula pétrea (art. 60, parágrafo $4^{\circ}$, inciso II).

O Conselho Federal defende que a ideia de Democracia pressupõe a igualdade política dos cidadãos. E, para isso, há de se conferir igual valor a todos os votos, conforme o princípio do "one man, one vote", de confecção norte-americana. Entretanto, o que acaba ocorrendo é que os votos possuem valor desigual, não de modo formal, mas sim material. A concentração de riqueza acaba por possuir muito mais força na disputa eleitoral em comparação aos menos privilegiados. Tal situação acaba por, inevitavelmente, formar uma aristocracia (governo das elites) e a Democracia acaba sendo deixada de lado em sua concepção material. Há, sim, uma Democracia eleitoral, em tese, entretanto, totalmente incapaz de ver realizada a concepção de Democracia de forma ampla e verdadeiramente presente na vida cidadã.

E é justamente isso que acaba ocorrendo no caso das normas jurídicas questionadas na Ação em questão, haja vista que permitem uma ampliação do poder político aos possuidores de vastas quantias em dinheiro, de seus apoiadores, aliados e financiadores, em detrimento dos demais eleitores que não são pertencentes a tal privilegiada classe.

Passando a uma argumentação relativa ao Princípio Republicano, disposto no artigo $1^{\circ}$ da Constituição Federal de 1988, o qual instituiu o Brasil como uma República Federativa, a OAB destaca que o Princípio Republicano não está limitado à mera instituição da forma de governo do Estado brasileiro. Para o Conselho Federal, a ideia de uma República é muito mais ampla, significando que os governantes e demais agentes públicos não atuarão na gestão de seus interesses individuais quando no controle da máquina pública, mas sim trabalharão em prol de defender tudo o que é de interesse público e coletivo. $\mathrm{Ou}$ seja, os gestores públicos estarão com a "coisa pública" em mãos, devendo servirem a ela, e não a seus interesses próprios.

É nesse sentido que, segundo o Conselho Federal da Ordem dos Advogados do Brasil no texto da petição inicial da Ação Direta de Inconstitucionalidade 4.650, o financiamento de campanhas por pessoas jurídicas e por pessoas naturais nos limites estabelecidos acaba por ferir o Princípio Republicano. Ou seja, o sistema existente no corpo das leis impugnadas fomenta uma competitividade eleitoral baseada, principalmente, no poder econômico. Dessa 
forma, para chegarem ao poder, os políticos se veem obrigados a buscar recursos de financiadores poderosos. E, assim, quando alcançado o cargo político almejado, acabam sendo obrigados a retribuir os favores prestados pelos citados financiadores, passando, então, a priorizarem interesses particulares de seus financiadores em detrimento do interesse público, gerando uma afronta evidente ao Princípio Republicano.

Ora, se a ideia de República é justamente a de que os agentes públicos promovam os interesses da coisa pública em vez de seus interesses particulares, um sistema de financiamento de campanhas eleitorais que faz com que os políticos façam justamente o contrário é patológico e acaba por desmanchar toda a ideia de República contida na Constituição Federal.

Superada a explanação dos argumentos trazidos pelo autor da ação, passa-se a uma análise sobre os principais argumentos favoráveis e contrários trazidos no julgamento pelo Supremo Tribunal Federal à procedência da referida Ação Direta de Inconstitucionalidade.

\subsection{Os argumentos pela procedência e improcedência da ação}

Superada a explanação dos argumentos trazidos pelo autor da ação, passa-se a uma análise sobre os principais argumentos favoráveis e contrários trazidos no julgamento pelo Supremo Tribunal Federal à procedência da referida Ação Direta de Inconstitucionalidade.

No presente tópico, serão mostradas as principais argumentações que foram desenvolvidas no curso do julgamento da Ação Direita de Inconstitucionalidade 4.650.

Buscar-se-á, de forma sintetizada, elucidar tanto argumentos favoráveis à procedência da ação quanto argumentos contrários, explanando a razão de ser de cada um.
Com isso, objetiva-se enriquecer ainda mais o debate sobre a questão do Financiamento de Campanhas Eleitorais no Brasil, bem como sua incidência na reforma política.

Um dos argumentos contrários à procedência da demanda é de que, apesar de o texto redigido na exordial considerar que o poder econômico pode interferir de forma negativa na Democracia e facilitar a corrupção, é inviável um bom sistema democrático sem partidos fortes e atuantes, o que requer alto custo financeiro. Um exemplo disso é que se considera um avanço na Democracia a possibilidade que os partidos políticos têm de acessar os espaços de rádio e televisão para propaganda eleitoral, o que é uma prática de elevados custos.

Outra justificativa em contrário é de que o problema da corrupção e do abuso do poder econômico não reside no texto normativo, mas sim na forma como o mesmo é aplicado. A solução, então, não seria extinguir a Lei, mas sim, melhorar os mecanismos de controle, fiscalização e punição. Em certo momento na história brasileira (a partir de 1971, com a Lei 5.682/71, revogada em 1995), era proibido que pessoas jurídicas financiassem campanhas eleitorais. Mesmo assim, existiam fraudes, corrupção e abuso. Foi justamente devido à situação da época que foi permitida a abertura às pessoas jurídicas na participação das doações a campanhas eleitorais.

Outro argumento apresentado para refutar a tese do Conselho Federal da Ordem dos Advogados do Brasil é o seguinte: a Constituição Federal não disciplina especificamente a matéria, tanto que a petição inicial trouxe como dispositivos feridos os que tratam dos princípios da Igualdade, da Democracia e Princípio Republicano, os quais são extremamente abertos e abrangentes, podendo ser aplicados a diversos casos. Sendo assim, as contribuições de pessoas jurídicas não podem ser consideradas totalmente incompatíveis com a Constituição Federal, haja 
vista que o texto constitucional não disciplina a questão de forma específica em nenhum momento.

Quanto às pessoas naturais, por ofensa ao princípio da igualdade, a Ordem dos Advogados do Brasil pede que seja declarada a inconstitucionalidade da norma que fixa o critério dos limites máximos de doação permitidos e da ausência de limite para o uso de recursos próprios dos candidatos, pois isso favorece candidatos mais abastados. O Conselho Federal pleiteia que o Supremo Tribunal Federal determine que o Congresso Nacional estabeleça um novo critério para os limites e que crie um limite para o uso dos recursos próprios dos candidatos. $\mathrm{E}$ se o Congresso Nacional não disciplinar tais questões, caberá ao Tribunal Superior Eleitoral fazê-lo provisoriamente.

Os julgadores contrários à procedência da ação respondem dizendo que não há bases constitucionais para que o Judiciário avance sobre atribuições típicas do Poder Legislativo. Além disso, por não ser viável que, pelo menos por Ação Direita de Inconstitucionalidade, o Supremo Tribunal Federal produza desde logo uma norma substitutiva, simplesmente declarar a inconstitucionalidade da norma do critério atual faria com que ficássemos sem limite algum, o que feriria mais ainda o princípio da Igualdade. Por fim, afirma-se que a desigualdade entre as pessoas reside no plano material e não normativo. Logo, qualquer que seja o critério adotado, ele não será capaz de reverter a desigualdade material.

Ademais, houve sustentação no sentido de que os pedidos seriam juridicamente impossíveis e a via eleita havia sido inadequada, haja vista que há cumulação de pedidos referentes a uma Ação Direta de Inconstitucionalidade e Ação Direta de Inconstitucionalidade por Omissão.

Do outro lado, um dos argumentos favoráveis à procedência da ação é a justificativa que uma das causas do afastamento hoje existente entre a sociedade civil e a classe política é a enorme influência que o poder econômico passou a ter no processo eleitoral brasileiro. O povo, muitas vezes, tem a sensação de que, devido ao dinheiro, o interesse privado fica acima do interesse público.

Outro argumento é de que a essência da Democracia é a igualdade. Logo, se o dinheiro é capaz de ofender essa igualdade, o atual modelo apresenta problemas e deve ser modificado.

Quanto ao Princípio Republicano, afirma-se que a ideia de República consiste em agente públicos administrando bens que não são seus privativamente, são públicos. No financiamento de campanhas por pessoas jurídicas, os agentes públicos (responsáveis pela gestão pública) fazem pactos com pessoas que possuem interesses privados, o que acaba ferindo tal princípio.

Ademais, os favoráveis à demanda, acolheram a justificativa do Conselho Federal da Ordem dos Advogados do Brasil no sentido de que caberia sim uma intervenção judicial no caso em tela, pelos motivos amplamente elencados pela OAB trazidos no item anterior deste texto. $\mathrm{Ou}$ seja, se a Democracia brasileira vem apresentando patologias, é papel do Supremo Tribunal Federal intervir e buscar corrigir tais injustiças, de modo a defender os interesses da sociedade civil como um todo, bem como garantir que o Princípio Republicano seja sempre observado na gestão do Estado.

Uma crucial justificativa para a legitimidade e procedência da demanda é de que a Constituição Federal, apesar de não ter abordado um modelo normativo específico para o tema do Financiamento de Campanhas Eleitorais, traçou limites para sua confecção. Ou seja, a Constituição Federal, ao positivar os princípios da Igualdade, da Democracia e da República delimita que o Financiamento de Campanhas Eleitorais seja feito respeitando-se tais postulados. Assim sendo, um sistema de financiamento de campanhas que vá contra tais princípios é sim inconstitucional e, portanto, 
passível de ser atacado por Ação Direta de Inconstitucionalidade.

Vistos os principais argumentos favoráveis e contrários à procedência da Ação Direta de Inconstitucionalidade 4.650, proposta pelo Conselho Federal da Ordem dos advogados do Brasil, foi possível enriquecer ainda mais o debate sobre o Financiamento de Campanhas Eleitorais. Restou evidente que tanto as argumentações favoráveis quanto as contrárias possuem fundamentações bem elaboradas e razoabilidade. Assim sendo, nota-se o porquê de o financiamento de campanhas eleitorais ser um tema tão complexo, sendo debatido há anos e, mesmo após o encerramento do debate no Supremo Tribunal Federal, segue aceso nas discussões cotidianas bem como no cenário político institucionalizado. Então, para uma maior definição sobre o tema, propõe-se agora a um relato sobre como o financiamento de campanhas eleitorais está disciplinado hoje no Brasil. É o que se aborda no item a seguir.

\subsection{Como fica o Financiamento no Brasil pós- contenda no STF?}

É inegável que a Ação Direta de Inconstitucionalidade 4.650 foi um marco histórico no debate do Financiamento de Campanhas Eleitorais. Entretanto, faz-se necessário destacar que sua ocorrência não colocou uma pedra sobre o referido assunto.

Apesar de o Supremo Tribunal Federal ter criado um patamar, as movimentações legislativas, bem como a revisão do debate, sempre serão possíveis, o que demonstra que o tema não se encerra.

Porém, no presente item, far-se-á um apanhado geral sobre como o Financiamento de Campanhas Eleitorais está sendo tratado no cenário político brasileiro pós-ocorrência da contenda nas mãos do Supremo Tribunal Federal.
Em um primeiro momento, faz-se mister destacar que Ação Direta de Inconstitucionalidade restou julgada parcialmente procedente, por um placar de 8 a 3, restando vencidos os Ministros Teori Zavascki, Celso de Mello e Gilmar Mendes. Os demais (Roberto Barroso, Joaquim Barbosa, o relator Luiz Fux, Ricardo Lewandowski, Dias Toffoli, Marco Aurélio, Carmen Lúcia e Rosa Weber) votaram pela procedência da Ação.

A razão de a demanda ter sido julgada parcialmente procedente é que, em relação às pessoas naturais, o Supremo Tribunal Federal acordou que suas contribuições ficariam regulamentadas pela legislação em vigor na época da propositura da ação.

Entretanto, após a publicação do Acórdão, entrou em vigor a lei 13.165 , de 29 de setembro de 2015. A referida Lei altera certos dispositivos das Leis 9.504 de 1997, 9.096 de 1995 e do Código Eleitoral (Lei 4.737 de 1965).

Entre outras alterações, revogou os artigos que permitiam doações de pessoas jurídicas a campanhas eleitorais, bem como os artigos que fixavam os limites para doações de pessoas jurídicas.

Dessa forma, na atualidade, o financiamento de campanhas eleitorais no Brasil funciona da seguinte forma: é um financiamento misto, ou seja, público e privado. A parte publica advém do fundo partidário, e a parte privada advém de pessoas naturais e de recursos do próprio candidato.

No caso das pessoas naturais, a lei 13.165 de 2015 manteve o disposto anteriormente, ou seja, limitação de $10 \%$ dos rendimentos brutos auferidos no ano anterior à eleição e estipulou o mesmo limite aos recursos próprios dos candidatos (artigo 23, §1 ${ }^{\circ}$, Lei 9.504 de 1997, após reformas sofridas em 2015). Ademais, estipula que tal limite não se aplica a doações estimáveis em dinheiro relativas à utilização de bens móveis ou imóveis de propriedade do 
doador, desde que o valor estimado não ultrapasse 80 mil reais.

O Fundo de Assistência Financeira aos Partidos Políticos, comumente chamado como Fundo Partidário, foi criado em 1965. Ele é composto de dotações orçamentárias da União, multas, penalidades, doações de pessoas físicas ou jurídicas feitas ao Fundo e demais recursos financeiros que lhe forem destinados por Lei, na forma do art. 38 da lei 9.096 de 1995.

O Fundo Partidário é distribuído da seguinte forma: 5\% dos recursos são divididos igualmente entre todos os partidos e $95 \%$ dos recursos são distribuídos de forma proporcional, baseado na quantidade de votos que o partido obteve para a Câmara dos Deputados levando em consideração as últimas eleições gerais ocorridas.

O Tribunal Superior Eleitoral distribui os recursos do Fundo a cada mês. Parte desse valor é um valor fixo, os chamados "Duodécimos", ou seja, a décima segunda parte da "parcela" de doze meses. Ademais, há um valor variável, advindo das multas eleitorais, o qual dependerá do valor arrecadado no referido mês em exercício.

A Lei 9.096 de 1995 estabelece, em seu artigo 44 que, da totalidade dos recursos recebidos do Fundo partidário por um partido, pelo menos $5 \%$ deverão ser utilizados na criação e manutenção de programas de promoção e difusão da participação política das mulheres e, pelo menos $20 \%$ deverão ser utilizados na criação e manutenção de instituto ou fundação de pesquisa e de doutrinação e educação política.

Em relação aos Diretórios Nacionais do Partido, no máximo 50\% do valor recebido poderá ser utilizado para pagamento de pessoal. Em relação a Diretórios estatuais e municipais, tal valor é de $60 \%$.

Com exceção dos percentuais mínimos de $5 \%$ e $20 \%$, o Partido é livre para despender do resto dos recursos da forma que entender adequada, desde que lícita. Logo, as campanhas eleitorais são apenas um dos diversos gastos nos quais o Fundo Partidário é aplicado.

Ademais, cabe salientar que a Lei 13.488 de 6 de outubro de 2017 reforça a proibição de doações de pessoas jurídicas a partidos políticos (e não só a campanhas eleitorais). Através dessa Lei, foi incluído um dispositivo no art. 31 da lei 9.096 de 1995 que dispõe tal vedação.

Também, é de suma importância destacar a recente criação, por parte do Congresso Nacional, com a sanção do Presidente Michel Temer, do Fundo Especial de Financiamento de Campanha, instituído pela Lei número 13.488 de 6 de outubro de 2017.

Com o objetivo de compensar o fim das doações de pessoas jurídicas às campanhas eleitorais, houve a recente criação do Fundo, o qual existirá paralelamente ao já estudado Fundo Partidário.

Estima-se que o Fundo Especial de Financiamento de Campanhas (FEFC), o qual já vigorará para as eleições de 2018, deva chegar a um valor de 1 bilhão e 700 mil reais para as próximas eleições segundo reportagens nos sites G1 (2017), Terra (2017) e EBC (2017).

$\mathrm{O}$ dinheiro do referido fundo será advindo de duas fontes: $30 \%$ das emendas de bancadas da Câmara e do Senado ao Orçamento e o resto do dinheiro que será economizado com o fim da propaganda partidária em rádio e TV (refere-se aqui, às propagandas particulares pagas, e não à propaganda eleitoral gratuita, que segue a existir).

Ademais, a utilização do Fundo Partidário segue em vigor. Para este, o site Terra estima que será atingido um valor de 1 bilhão de reais para as próximas eleições, a serem realizadas em 2018.

A distribuição dos recursos do FEFC se dará da seguinte forma, conforme artigo 16-D da Lei 13.488 de 2017.

Art. 16-D. Os recursos do Fundo Especial de Financiamento de Campanha (FEFC), para o primeiro turno das eleições, serão distribuídos entre 
os partidos políticos, obedecidos os seguintes critérios:

I - $2 \%$ (dois por cento), divididos igualitariamente entre todos os partidos com estatutos registrados no Tribunal Superior Eleitoral;

II - 35\% (trinta e cinco por cento), divididos entre os partidos que tenham pelo menos um representante na Câmara dos Deputados, na proporção do percentual de votos por eles obtidos na última eleição geral para a Câmara dos Deputados;

III - $48 \%$ (quarenta e oito por cento), divididos entre os partidos, na proporção do número de representantes na Câmara dos Deputados, consideradas as legendas dos titulares;

IV - $15 \%$ (quinze por cento), divididos entre os partidos, na proporção do número de representantes no Senado Federal, consideradas as legendas dos titulares.

Por fim, reportagens de sites como Estadão (2017), Revista Forum (2017), Correio do Povo (2017) e Veja (2017), atentam para a criação do "Fundo Cívico para a Renovação da Política" ou "Fundo Renova BR", uma criação de um grupo de empresários como Luciano Huck, o expresidente do Banco Central Armínio fraga e Abílio Diniz.

Tal fundo funcionaria com a concessão de bolsas de estudos de 5 mil reais mensais a interessados em se candidatar ao Legislativo nas eleições de 2018. A intenção do grupo seria tentar eleger de setenta a cem deputados federais na próxima eleição.

As reportagens destacam, ainda, que o deputado Jorge Solla (PT-BA) pediu à Procuradoria-Geral da República uma investigação sobre o referido fundo, alegando que há a possibilidade de o mesmo ser uma tentativa de burlar a proibição de pessoas jurídicas a doarem para campanhas eleitorais, bem como um caixa dois travestido. Isso porque, segundo o deputado, o fundo seria na prática uma pessoa jurídica disfarçada, já que, segundo Gonçalves (2005, p. 127), “a pessoa jurídica consiste num conjunto de pessoas ou bens, dotado de personalidade jurídica própria e constituído na forma da Lei para a consecução de fins comuns". Ademais, o deputado solicitou também a suspensão liminar do Fundo.

As atividades do grupo responsável pelo fundo já começaram, através do início das seleções de quais pessoas seriam as mais adequadas para o recebimento das bolsas, ou seja, os potencias candidatos ao Parlamento.

Enfim, é notável que recursos como o Fundo Renova BR e o FEFC provam que o debate sobre o financiamento de campanhas eleitorais não se encerrou com a conclusão da Ação Direta de Inconstitucionalidade 4.650. Estão se buscando formas de recuperar o dinheiro perdido pelo fim das doações de pessoas jurídicas ou então de burlar sua proibição.

Arrisca-se dizer que, talvez, a problemática relativa ao financiamento de campanhas eleitorais no Brasil tenha mais a ver com a corrupção sistematizada e com a moralidade política dos representes eleitos bem como dos cidadãos e não tanto com uma mera normatização sobre a matéria.

Outro aspecto interessante relativo ao Financiamento de Campanhas Eleitorais é que houve mais um caso de Judicialização da Política no caso da ADI 4.650, tema que se passa a abordar no próximo capítulo.

\section{A JUDICIALIZAÇÃO DA POLÍTICA NO CASO DA ADI 4.650}

No presente item, abordar-se-á mais um dos aspectos debatidos sobre o Financiamento de Campanhas Eleitorais no trabalho em questão: a Ação Direta de Inconstitucionalidade número 4.650 configurando mais um dos casos de Judicialização da Política ocorridos no Brasil.

De forma genérica, pode-se dizer que a Judicialização da Política é um fenômeno que consiste na tendência moderna de intervenção do

${ }^{5}$ Veja em: <http://renovabr.org>. Acesso em: 27 set. 2017. 
Poder Judiciário em assuntos de política. Trata-se do repasse do poder de decisão sobre assuntos políticos para o Judiciário, sendo que, em tese, a competência para tratar de tais temas em uma Democracia seria dos poderes Legislativo e Executivo, os quais possuem de fato cunho político em sua consistência, diferentemente no Judiciário, que deveria exercer um papel vigilante e imparcial na condução do aparato democrático.

Há algumas décadas se debate a reforma política no Brasil, sempre cobrando que o Legislativo opere no sentido de alterar o modo como corre o processo eleitoral. Entretanto, a grande decisão acerca do financiamento de campanhas eleitorais foi tomada pelo Supremo Tribunal Federal, em mais um caso de judicialização da política. Segundo Tate (1995, apud CASTRO, 1997, p. 10), “[a] interação dos Tribunais com o sistema político tem atraído a atenção de cientistas sociais recentemente. A forma dessa interação depende de diversos fatores, que podem variar de sociedade para sociedade". Tal fenômeno ocorre quando o judiciário avança sobre competências que, $a$ priori, deveriam pertencer a um dos outros dois poderes, ferindo o clássico princípio da separação dos poderes outrora proposto por Montesquieu.

Afirma Montesquieu que uma experiência eterna atesta que todo homem que detém o poder tende a abusar do mesmo.

Vai o abuso até onde se lhe deparem limites. E para que não se possa abusar desse poder, faz-se mister organizar a sociedade política de tal forma que o poder seja um freio ao poder, limitando o poder pelo próprio poder (BONAVIDES, 2006, p. 148).

A teoria de Montesquieu sobre a separação dos poderes foi adotada em nossa Constituição Democrática de 1988. Ou seja, a Constituição está redigida em observância à tripartição dos poderes ora estudada. Assim, de forma genérica, conforme descrito por Montesquieu e, ao se fazer uma leitura de nossa Constituição Federal de 1988, depreende-se a existência dos três grandes poderes: Legislativo, Judiciário e Executivo. Observa-se isso de forma expressa no artigo segundo da Constituição Federal de 1988, que assim dispõe em seu texto: "São Poderes da União, independentes e harmônicos entre si, o Legislativo, o Executivo e o Judiciário.".

Ademais, cabe salientar que a ideia de Montesquieu não expressa somente uma separação de poderes de forma isolada. Em verdade, faz parte do conceito geral de tripartição de poderes o sistema de "checks and balances", ou seja, sistema de freios e contrapesos. Segundo tal preceito, os poderes existiriam entre si de forma independente, porém em concomitância. Ou seja, deve haver uma harmonização dos poderes de forma que um fiscalize o outro, freando a preponderância de um sobre os demais, a fim de evitar a tirania de um dos poderes. Para isso, o respeito à Constituição e às garantias constitucionais é fundamental.

O maior problema do fenômeno da Judicialização da Política e da extrema incidência da jurisdição constitucional é que ela acaba por descaracterizar a real ideia de Democracia. Isso porque o princípio fundamental da Democracia é o poder nas mãos do povo, o que se desenvolve, na prática, através dos representantes eleitos. Assim sendo, espera-se de uma Democracia saudável que a maior parte das decisões políticas e sobre os rumos do Estado sejam tomadas pelos representantes do povo, de forma a consolidar o poder popular. Entretanto, o que tem ocorrido, é uma tomada à frente das decisões pelo Poder Judiciário, setor este que não é formado por eleitos pelo povo. Assim, a Judicialização da Política é um fenômeno que, entre outros efeitos, acaba por enfraquecer o poder popular e a representatividade.

O poder legislativo do povo através dos seus representantes eleitos é a dimensão essencial da democracia e que a jurisdição constitucional é uma restrição à democracia na medida em que retira, pelo menos em parte, à lei a sua força. (...) A teoria 
jurisdicional vê, portanto, na jurisdição constitucional um limite ou uma restrição ao princípio do governo do povo pelo povo (BRITO, 1995, p. 39).

Dessa forma, ao julgar uma matéria que diz respeito à Reforma Política, o Judiciário brasileiro acaba avançando na competência dos dois poderes que são tipicamente políticos: o Executivo e o Legislativo. Não se quer aqui afirmar que o STF agiu de forma ilegal ao julgar a ADI em questão. O judiciário deve responder à sociedade, quando provocado. $\mathrm{O}$ que se questiona é a omissão do Legislativo, ocasionando a chegada de tais questões à esfera judicial, mesmo não sendo este o poder competente para decidir os rumos da política. Tanto é que, ao encerrar, seu voto, o ministro Barroso defende a reforma política e afirma que essa deve ser realizada pelo Legislativo, pois ao Judiciário falta competência para tanto.

Em verdade, a forma como os poderes estão estruturados no Brasil, bem como o aparato legislativo como um todo é que permite a atual supremacia do judiciário frente aos outros poderes. A organização institucional brasileira permite, basicamente, que qualquer demanda chegue ao judiciário. E, em relação à jurisdição constitucional, exercida pelo Supremo Tribunal Federal, há uma abertura que ocasiona a chegada de um leque variado às suas mãos. É diferente do que ocorre em outros países como os Estados Unidos, por exemplo, onde a Suprema Corte de julga pouquíssimas demandas a cada ano, pois é restrito o tipo de matéria que pode atrair a competência do referido órgão jurisdicional norte-americano.

Então, não se pode alegar que o judiciário brasileiro está agindo de forma ilegal ou em desrespeito às regras institucionais postas ao julgar demandas políticas como o caso da Ação Direta de Inconstitucionalidade 4.650. O fato é que, a forma como está organizado o Estado brasileiro e a legislação relativa à competência de cada poder permite que, de forma legítima, um imenso número de demandas atinja o poder Judiciário.

Ademais, talvez o principal motivo para a Judicialização da Política seja a inércia acometida nos poderes precipuamente políticos, que são o Legislativo e o Executivo. Ao ignorarem matérias de suma importância ao desenvolvimento da vida política e cidadã do Estado, os legisladores brasileiros abrem portas para um crescimento cada vez mais acelerado do fenômeno da Judicialização da Política no Brasil.

Também, mais perigosa que a omissão pura e simples, ou seja, deixar de legislar, é a omissão aos interesses populares. Assim, ao trabalharem em intensa produção legislativa, porém sem observância das pautas do povo e da supremacia da coisa pública, mas sim de interesses próprios e particulares, a atividade dos poderes políticos acaba sendo nociva. Tal cenário também gera um clamor pelo Poder Judiciário como guardião da moralidade e "herói" a resolver as mazelas da classe política.

Em suma, observa-se que a Judicialização da Política no Brasil é um fenômeno cada vez mais recorrente, bem como restou evidente sua ocorrência no caso da Ação Direta de Inconstitucionalidade 4.650, na qual o Supremo Tribunal Federal julgou um tema central para a definição dos rumos da política no Brasil: o Financiamento de Campanhas Eleitorais.

Faz-se necessário que se atente para a evolução do fenômeno, a fim de que se evite a tiraria de um poder frente aos demais e ao povo, ou seja, justamente a problemática que Montesquieu buscava evitar ao criar a ideia da tripartição dos poderes, ora fragilizada na Democracia brasileira em tantos aspectos.

\section{CONCLUSÃO}

As discussões abordadas neste trabalho permitem algumas conclusões e considerações 
acerca do Financiamento de Campanhas Eleitorais na Democracia brasileira. É o que se verá desde logo.

Em primeiro lugar, ficou evidente que o Financiamento de Campanhas Eleitorais é tema de suma importância quando se fala em Reforma Política, sendo, inclusive, um dos aspectos da reforma política mais discutidos (se não o mais discutido) na atualidade. Resta claro o quanto é primordial levantar o assunto e os debates sobre financiamento de campanhas ao se buscar traçar uma Reforma Política para o Brasil. Isso se deve ao fato de que a forma como o Financiamento de Campanhas Eleitorais for regulamentada e tratado dirá muito sobre os rumos tomados pela política brasileira, já que são as eleições (e, logo, as campanhas eleitorais) o modo de que se chegar ao poder.

Depois, mostrou-se uma coletânea sobre o histórico legislativo do Financiamento de Campanhas Eleitorais no Brasil, ou seja, de que forma as Leis trataram o assunto ao longo da história brasileira. Observou-se que o financiamento de campanhas eleitorais positivado é mais recente que as próprias eleições no Brasil. Entretanto, assim que o dinheiro passou a ter forte na sociedade, passou-se à preocupação de sua abordagem no pleito. O referido tópico também demonstrou que a legislação continua constantemente revisitando o assunto do Financiamento de Campanhas Eleitorais. Ou seja, desde a primeira regulamentação sobre o tema, diversas outras Leis foram criadas e continuam sendo revistas até hoje, da mesma forma que novas legislações seguem sendo criadas.

Então, no tópico subsequente, foram analisados os existentes modelos de financiamento de campanhas: financiamento misto (que é o caso do Brasil), financiamento público e financiamento privado. No referido item foi esclarecida a forma como funcionam cada um dos sistemas de financiamento de campanhas existentes. Também, estabeleceram-se alguns pontos favoráveis e contrários à aplicação de cada um deles. Ambos apresentam aspectos positivos e negativos, sendo necessário analisar qual deles melhor se encaixa no contexto democrático do Brasil.

Posteriormente, analisou-se a chegada da contenda sobre o Financiamento de Campanhas Eleitorais ao Supremo Tribunal Federal através de uma Ação Direta de Inconstitucionalidade proposta pelo Conselho Federal da Ordem dos Advogados do Brasil: a ADI 4.650. Foram abordados os argumentos trazidos pela $\mathrm{OAB}$ para a propositura da ação, bem como os argumentos elencados pelos julgadores no trâmite da mesma. Com isso, foi possível observar que, no que tange ao debate sobre o Financiamento de Campanhas Eleitorais, argumentos de ambos os lados apresentam fundamento, o que torna um debate extremante rico, mas também complexo, por outro lado.

Ademais, foi essencial que se demonstrasse de que forma restou a tratativa do Financiamento de Campanhas Eleitorais no Brasil após o importante marco do julgamento e publicação do acórdão da Ação Direta de Inconstitucionalidade 4.650. Assim, foi possível concluir que de forma alguma a referida contenda encerrou o debate sobre o assunto. Isso porque, já após a decisão final, houve edições de novas legislações e demais institutos que tratam do financiamento de campanhas. Alguns, inclusive, como uma possível tentativa de divergir do teor da referida decisão.

Por fim, abordou-se de forma crítica a chegada do debate do Financiamento de Campanhas Eleitorais ao Supremo Tribunal Federal através da Ação Direta de Inconstitucionalidade 4.650 como sendo mais um caso de Judicialização da Política no cenário brasileiro. Para tanto, demonstrou-se no que consiste o fenômeno da Judicialização da Política, bem como suas causas e consequências. Além disso, procurou-se entender como a crescente 
incidência da Judicialização da Política provoca máculas à Teoria da Tripartição dos Poderes proposta por Montesquieu. E, já que tal teoria fora consagrada em nossa Constituição Federal, a demasiada intervenção da jurisdição constitucional no ordenamento político acaba por ferir o próprio texto constitucional bem como a ideia de Democracia.

Em suma, ficou bastante clara a importância e complexidade do tema do Financiamento de Campanhas Eleitorais no Brasil. Sua importância se dá, principalmente, devido ao fato de que é um fator essencial na definição dos rumos que tomarão as campanhas eleitorais, as eleições e, consequentemente, o funcionamento da Democracia e da governabilidade dos eleitos. Ademais, é um tema complexo por possuir diversas facetas. Como se observou no presente trabalho, o assunto possui aspectos históricos, sociais, econômicos, judiciais, legislativos, doutrinários. Todos são de extrema relevância para uma compreensão sobre o assunto. Complexo também por possuir fundamento em seus diferentes tipos de argumentações, mesmo que seja uma divergente da outra. Além disso, é um tema de recorrente revisão por parte dos políticos e da sociedade, não se esgotando seu debate cívico e nem político mesmo após grandes e importantes decisões.

Por fim, conclui-se ser salutar que sempre se reveja os assuntos relativos à política e à Democracia e, entre eles, evidentemente, o Financiamento de Campanhas Eleitorais. Também, resta claro que a mera positivação da política em leis escritas não é suficiente para a solução de todas as mazelas da Democracia brasileira. Ou seja, é fundamental que se diga que não existe reforma política sem reforma do pensamento político, que, por sua vez, pressupõe uma reforma da educação e uma reforma ética das condições econômicas e sociais do modo de viver. 


\section{REFERÊNCIAS}

AFFONSO, Julia; MACEDO, Fausto. Deputado vai a Raquel para suspender fundo eleitoral de Huck. Brasil: Estadão, 2017. Disponível em: <http://politica.estadao. com.br/blogs/fausto-macedo/deputadovai-a-raquel-para-suspender-fundo-eleitoral-de-huck/>. Acesso em: 13 out. 2017.

BARROSO, Luís Roberto. Voto na ADI 4.650/DF. Relator Ministro Luiz Fux. Brasília: Supremo Tribunal Federal, 2014. Disponível em: <http://www.luisrobertobarroso.com.br/wpcontent/uploads/2014/05/Voto-sobre-financiamento-de-campanha-ADI-46501.pdf>. Acesso em: 17 jul. 2014.

BONAVIDES, Paulo. Ciência Política. 12a ed. São Paulo: Malheiros Editores, 2006.

BRASIL. Lei 13.488. Brasília: Planalto, 2017. Disponível em: <http://www.planalto .gov.br/ccivil_03/_Ato2015-2018/2017/Lei/L13488.htm\#art2>. Acesso em: 13 out. 2017.

BRITO, José de Souza. Tribunal Constitucional - Legitimidade e Legitimação da Justiça Constitucional - Jurisdição constitucional e princípio democrático. Coimbra: Coimbra Editora, 1995.

CAGGIANO, Monica Herman S. Corrupção e Financiamento das Campanhas Eleitorais. In: ZILVETI, Fernando Aurelio; LOPES, Silvia (Orgs.). O Regime Democrático e a Questão da Corrupção Política. São Paulo: Atlas, 2004.

CASTRO, Marcos Faro de. O Supremo Tribunal Federal e a Judicialização da Política. Revista Brasileira de Ciências Sociais, v. 12, n. 34, p. 1-13, jun. 1997.

CORREIO do Povo. Deputado recorre à PGR para suspender fundo eleitoral de Luciano Huck. Porto Alegre: Correio do Povo, 2017.2 Disponível em: <http://www.correiodopovo.com.br/Noticias/Politica/2017/10/630413/Deputado-recorre-a-PGRpara-suspender-fundo-eleitoral-de-Luciano-Huck>. Acesso em: 13 out. 2017.

FLEISCHNER, David; LÚCIO, Magda de Lima; REIS, Márlon Jacinto. Reforma política, instituições eleitorais e capital social. Brasília: Secretaria de Assuntos Legislativos do Ministério da Justiça, 2009. (Série Pensando o Direito, n.20).

FÓRUM SOCIAL BRASILEIRO. Plataforma da Reforma do Sistema Político Brasileiro (Versão para debate). [S.1.: s.n., 2014?].

G1. Reforma Política: veja o que muda nas regras da eleição 2018. São Paulo: G1, 2017. Disponível em: <https://g1.globo.com/politica/noticia/reforma-politica-veja-o-que-muda-nas-regras-da-eleicao2018.ghtml>. Acesso em: 13 out. 2017.

LIMA, Elias Máximo de. Reforma Política: Voto em lista fechada na democracia representativa. 2010. Monografia (Especialização em Política e Representação Parlamentar) - Centro de Formação, Treinamento e Aperfeiçoamento da Câmara dos Deputados.

MACHADO, Marcelo Passamani. O financiamento das campanhas eleitorais: perspectivas para uma reforma política. In: CAGGIANO, Monica Herman S. (Org.). O voto nas Américas. São Paulo: Minha Editora, 2008. 
MARTINS, Ives Gandra da Silva. Reflexões Constitucionais sobre Financiamento de Campanhas Eleitorais. In: ZILVETI, Fernando Aurelio; LOPES, Silvia (Orgs.) O Regime Democrático e a Questão da Corrupção Política. São Paulo: Atlas, 2004.

MELO, Karine. Reforma Política: saiba o que muda nas eleições de 2018. Brasília: EBC, 2017. Disponível em: <http://agenciabrasil.ebc.com.br/politica/noticia/2017-10/reforma-politica-saiba-oque-muda-nas-eleicoes-de-2018>. Acesso em: 13 out. 2017.

PEREIRA, Rodolfo Viana; VIDAL, Luísa Ferreira. Big Donors Brasileiros: Retrato das 10 (Dez) Empresas que Mais Doaram Para as Campanhas e Para os Diretórios Nacionais dos Partidos Políticos dos Candidatos à Presidência da República nas Eleições de 2010. In: COSTA, Mônica Aragão M. F. Costa; GUERRA, Arthur Magno e Silva; RIBEIRO, Patrícia Henriques (orgs.) Direito Eleitoral: Leituras Complementares. Belo Horizonte: Editora D’Plácido, 2014.

RBA. "Fundo Eleitoral" de Huck e outros empresários é tentativa de legalizar caixa 2. Brasil: Revista Forum, 2017. Disponível em: <https://www.revistaforum. com.br/2017/10/04/fundo-eleitoral-dehuck-e-outros-empresarios-e-tentativa-de-legalizar-caixa-2/>. Acesso em: 13 out. 2017.

REDAÇÃO, Da. Deputado petista pede à PGR suspensão de Fundo Eleitoral de Huck. Brasil: Editora Abril, 2017. Disponível em: <http://veja.abril.com.br/politica /deputado-petista-pede-a-pgr-suspensaode-fundo-eleitoral-de-huck/\#>. Acesso em: 13 out. 2017.

RIBEIRO, Renato Janine. Financiamento de Campanha (público versus privado). In: ANASTASIA, Fátima; AVRITZER, Leonardo. (Orgs.) Reforma Política no Brasil. Belo Horizonte: Editora UFMG, 2006.

STRUCK, Jean-Philip. O financiamento público de campanhas pelo mundo. Brasil: DW, 2018. Disponível em: <http://www.dw.com/pt-br/o-financiamento-público-de-campanhas-pelo-mundo/a40047536>. Acesso em: 25 jul. 2017.

TEIXEIRA FILHO, Althen. Financie um candidato: compre um político. 2.ed. Pelotas: Editora do Autor, 2013.

TERRA. Reforma Política: o que muda e o que continuará igual para as eleições de 2018. Brasil: Terra, 2017. Disponível em: <https://www.terra. com.br/noticias/brasil/reforma-politica-o-que-mudae-o-que-continuara-igual-para-as-eleicoes-de-2018,0240d99fafaad9ceb6 ce134fb7b61f64rjkndz4j.html>. Acesso em: 13 out. 2017.

Tribunal Superior Eleitoral. Fundo Partidário. Disponível em: <http://www.tse.jus.br/partidos/fundopartidario>. Acesso em: 11 abr. 2015.

ZAVASCKI, Teori Albino. Voto na ADI 4.650/DF. Relator Ministro Luiz Fux. Brasília: Supremo Tribunal Federal, 2014. Disponível em: <http://s.conjur.com.br/dl/voto-teori-zavasckifinanciamento.pdf>. Acesso em: 17 jul. 2014. 
